\title{
LUT
}

University

\section{Business Strategies in Internationalisation Outcomes among SMEs}

Torkkeli Lasse, Saarenketo Sami, Kuivalainen Olli, Puumalainen Kaisu

This is a Final draft version of a publication

published by Palgrave Macmillan

in Tüselmann, H., Buzdugan, S., Cao, Q., Freund, D., Golesorkhi, S. (Eds.) Impact of International Business: Challenges and Solutions for Policy and Practice

DOI: $10.1007 / 978-1-137-56946-2 \_7$

Copyright of the original publication: (c) Torkkeli, Saarenketo, Kuivalainen, Puumalainen 2016

Please cite the publication as follows:

Torkkeli, L., Saarenketo, S., Kuivalainen, O., Puumalainen, K. (2016). Business Strategies in Internationalisation Outcomes among SMEs. In: Tüselmann, H., Buzdugan, S., Cao, Q., Freund, D., Golesorkhi, S. (Eds.) Impact of International Business: Challenges and Solutions for Policy and Practice. Palgrave Macmillan. pp. 95-111. DOI: 10.1007/978-1-137-56946-2_7

This is a parallel published version of an original publication. This version can differ from the original published article. 


\section{Business Strategies in Internationalization Outcomes among SMEs}

Lasse Torkkeli,

Lappeenranta University of Technology, School Of Business and Management P.O.BOX 20, FI-53851 Lappeenranta

e-mail: lasse.torkkeli@lut.fi

Olli Kuivalainen,

Lappeenranta University of Technology, School Of Business and Management P.O.BOX 20, FI-53851 Lappeenranta

e-mail: olli.kuivalainen@lut.fi

Sami Saarenketo,

Lappeenranta University of Technology, School Of Business and Management P.O.BOX 20, FI-53851 Lappeenranta

ë-mail:sami.saarenketo@,lut.fi

Kaisu Puumalainen,

Lappeenranta University of Technology, School Of Business and Management P.O.BOX 20, FI-53851 Lappeenranta

e-mail: kaisu.puumalainen@,lut.fi

Cite as: Torkkeli, L., Saarenketo, S., Kuivalainen, O. \& Puumalainen, K. (2016). Business Strategies in Internationalisation Outcomes among SMEs. In: Tüselmann, H., Buzdugan. S., Cao, Q., Freudn, D. \& Golesorkhi, S. (Eds.): Impact of International Business: Challenges and Solutions for Policy and Practice, Palgrave MacMillan: New York., pp 95-111. DOI: https://doi.org/10.1007/978-1-137-56946$\underline{2} 7$ 


\begin{abstract}
Business strategies focused on unique products development and quality have been found to determine the international success of rapidly internationalizing firms known as "born globals". However, it remains unclear if these strategies are also applicable in the context of internationalizing small- and medium-sized enterprises (SMEs) in general. Thus, by applying a cross-sectional sample of 119 Finnish SMEs collected in 2008, we examine how the two business strategies determine internationalization outcomes among SMEs. We find that: 1) unique products development is a differentiating factor between born globals and other SMEs, and is linked to increased turnover growth at the start of internationalization, 2) the quality focus has no such effects, and 3) neither of the focal strategies are linked to increased international performance.
\end{abstract}

Keywords: Internationalization of SMEs, Strategy of SMEs, Born Globals, International Performance 


\section{Business Strategies in Internationalization Outcomes among SMEs}

\section{INTRODUCTION}

In this paper, we investigate the influence of business strategies upon the internationalization of SMEs. In particular, we investigate the effect of strategic aim for unique products development and quality focus, the two business strategies suggested to be linked to the international performance of rapidly internationalizing firms by Knight and Cauvsgil (2004). These firms have been defined as "born globals" (Rennie, 1993; Knight and Cavusgil, 1996; Madsen and Servais, 1997), and in Knight and Cavusgil's 2004 article (see also Cavusgil and Knight, 2015), these business strategies, along with leveraging organizational competences were suggested as acting as main intermediators of strategic orientation towards their increased performance.

In this paper, we suggest that the result is both interesting and in need of further elaboration for several reasons. First, much of the scholarly research on born globals has been conducted in the field of international entrepreneurship, or "the discovery, enactment, evaluation, and exploitation of opportunities - across national borders - to create future goods and services" (Oviatt and McDougall, 2005, p.540), where the discussion of business strategies has tended to concentrate on managerial decision-making related to internationalization and entry mode decisions (Spence, 2003; Levesque and Shepherd, 2004; Gleason and Wiggenhorn, 2007; Tuppura et al., 2008) rather than product, service and customer strategies as such. Thus, the role of strategic frameworks such as global marketing strategies (Zou and Cavusgil, 2002) and export marketing strategies (Cavusgil and Zou, 1994) has received less attention in the literature on born globals and on international entrepreneurship in general. 
Second, while the argument can be made that smaller firms may, in general, have less formalized and pre-planned strategies for internationalization, Knight and Cavusgil (2004) found that certain strategic focuses may be relevant even for the most rapidly internationalizing firms. This implies that studying business strategies in a more formal sense may also be called for in the context of smaller internationalizing firms as well.

Third, more elaboration is called for in terms of different types of internationalizing firms, particularly SMEs. Born globals have been defined in various ways (see Gabrielsson et al. 2008). The review of international entrepreneurship studies by Jones et al. 2011 concludes that the term "born global" is generally considered to encompass firms that internationalize early and rapidly, with Knight and Cavusgil (2004, p. 124) defining born globals as "business organizations that, from or near their founding, seek superior international business performance from the application of knowledge-based resources to the sale of outputs in multiple countries". While this definition does not restrict born globals by the size of the firm, other studies have denoted them as small knowledge-intensive firms (Knight, 1996; Moen, 2002; Gabrielsson et al., 2008), which they often tend to be, particularly in small open economies with limited domestic markets and the prevalence of niche-oriented hightechnology startups. Thus, they can be contrasted to non-born globals, i.e., internationalizing SMEs that do not fit the definition of a born global.

This contrasting may be relevant in order to elaborate on the internationalization business strategies of different types of small firms, particularly as an earlier exploratory study by Bell et al. (2004) found differences between business strategies and internationalization of firms from knowledge-intensive and more traditional manufacturing fields. This implies that the 
dynamics of business strategies may vary between born globals and other types of internationalizing small firms.

For these reasons, we consider it relevant to continue the investigation by Knight and Cavusgil (2004) and examine the relevance of the business strategies of SMEs to their internationalization. In doing so, we aim to investigate whether the relevance of the business strategy varies between born globals and other types of internationalizing SMEs, whether strategic focus is linked to more rapid foreign expansion in SMEs overall, and whether the positive influence of the product development- and quality-focused strategies on international performance of born globals (Knight and Cavusgil, 2004) are also generalizable to SMEs as a whole.

The paper is constructed as follows: the next section discusses the theoretical background and the extant literature on the topic of business strategies and internationalization of SMEs, and consequently presents our hypotheses derived from the literature review. The third section of this paper explicates the empirical data and the research methods used, with the fourth section presenting the results of the empirical analysis. The fifth section discusses the policy and practical implications of the results, and we conclude in section six by assessing the limitations of this study and potential future research avenues.

\section{LITERATURE REVIEW}

Born globals are the type of firms that by nature seek to internationalize earlier and more intensely than more traditional types of SMEs. In doing so, their emergence has challenged 
the traditional models of internationalization, such as the "Uppsala model" (Johanson and Wiedersheim-Paul, 1975; Johanson and Vahlne, 1977; 2003; 2009) that have tended to present internationalization in the SME context as a gradual learning process. The emergence of new knowledge-intensive industry sectors such as the software industry (Bell, 1995) has, in particular, often presented scholars with a host of small firms that tend to leap-frog some of the stages in the internationalization process suggested by the traditional models. Accordingly, various typologies and definitions of these firms have risen in the field of international entrepreneurship (see Jones et al., 2011).

In this study, we concentrate on the difference between born globals and other types of SMEs. With the former, we adhere to the definition by Knight and Cavusgil (1996) and Knight et al. of born globals that (2004, p.649) "is consistent with those used to operationalise other studies on born-global firms", where born globals are those firms that have: 1) begun internationalizing within three years of firm foundation and 2) generate at least a quarter of their total sales from abroad. Similarly, when discussing SMEs, we refer to firms employing less than 500 people (OECD, 2008; Knight, 1996).

Overall, organizational emergence in said to occur through the actions taken by the organization rather than its characteristics, i.e., through achieving strategic rather than conforming legitimacy (Tornikoski \& Newbert, 2007). In the context of internationalization, the seminal study by Knight and Cavusgil (2004) found that international strategic orientations in born global firms come to determine their business strategies, two of which are related to leveraging the organizational competences and the competences of foreign distributors for the firm. There are also two main strategies related to the products of the firm: those related to unique products development and quality focus, strategies which in turn lead 
to increased performance in international markets. In particular, unique products development "reflects the creation of distinctive products, and is akin to differentiation strategy, which involves creating customer loyalty by uniquely meeting a particular need.” (Knight and Cavusgil 2004, p. 131). Accordingly, quality focus "reflects efforts to develop products that meet or exceed customer expectations with respect to features and performance." (Ibid., p.131) These definitions, taken together with the results of the study, imply that for born globals, a strategy focused on delivering innovative products that respond to the needs of, and meet the expectations of the customers of the firm will result in increased success in global markets. On the other hand, however, strategy formation of SMEs has been suggested to occur through to opportunistic behavior (Crick \& Spence, 2005), and their internationalization process through serendipity (Merrilees et al., 1998; Meyer \& Skak, 2002).

Consequently, we could assume that the beneficial effects of such strategies are more clearly seen in born globals, compared to internationalizing SMEs in general. For one, enterprises that internationalize early tend to apply strategies appropriate to their unique characteristics, such as age and size (Cavusgil and Knight, 2015). Market response to the internationalization of born globals can be distinctly positive (Gleason and Wiggenhorn, 2007), and globalization tends to facilitate conduction of born global strategies (Andersson and Wictor, 2003). As born global -type firms tend to be in abundance, particularly in innovative high-technology sectors, it is therefore not surprising that innovative product development and focus upon quality is linked to increased success among these firms.

However, the internationalization process and the accompanying strategies may be different in more traditional manufacturing firms (see Bell et al., 2004). Thus, we might expect not only that these business strategies are linked to performance among born globals (as 
suggested by Knight and Cavusgil, 2004), but also that other types of internationalizing SMEs might not benefit from these strategies in equal measure. This would imply that SMEs with more focused business strategies would tend to be born globals, rather than non-born globals:

- H1: The higher the focus of an SME on unique products development, the more likely it is a born global.

- H2: The higher the quality focus of an SME, the more likely it is a born global.

Similarly, once an SME enters their first foreign market, and thus turns from a domestic into an international operator, we could expect their product development- and quality focused business strategies to lead to increased growth. This would be in line with the definition of born globals as firms that not only internationalize early, but also do so intensely, acquiring a large share of their turnover from abroad within a few years of starting their internationalization process (e.g., Rennie, 1993; Knight and Cavusgil, 1996; Chetty and Campbell-Hunt, 2003). If born globals in particular tend to benefit from such strategic focus, we might posit that the more focused SMEs are in their business strategies, the more rapidly they are likely to be able to grow abroad:

- H3: The higher the focus of an SME on unique products development, the more rapid its growth in international markets.

- H4: The higher the quality focus of an SME, the more rapid its growth in international markets.

Finally, Knight and Cavusgil (2004) explicitly linked these business strategies to the increased international performance of born globals. In doing so, they applied a measure based on managerial assessment of the extent of performance related to the prior expectations of the managers, as well as of the extent of success with products and compared to the main 
competitors of the respondents. We refer to this performance as "subjective international performance" (as opposed to e.g., degree of internationalization calculated directly from the absolute amount of foreign sales or the number of countries in which the firm operates), and posit that this applies to internationalizing SMEs in general:

- H5: The higher the unique products development of an SME, the better its subjective international performance.

- H5: The higher the quality focus of an SME, the better its subjective international performance.

\section{RESEARCH METHODOLOGY}

\section{$\underline{3.1 \text { Data Collection }}$}

The empirical data to test the hypotheses were collected in Finland via an online survey during the first half of 2008 (February-July). We considered the country context relevant due to much of the extant research on born globals, having found the phenomenon particularly prevalent in small open economies such as Finland (e.g., Autio et al., 2000; Jantunen et al. 2008; Kuivalainen et al., 2007; Laanti et al., 2007; Tuppura et al., 2008). Moreover, a crosssectional sample of SMEs was sought that would include both knowledge-intensive and less knowledge-intensive firms across several industry sectors, as knowledge-intensiveness has been noted as a major factor distinguishing between born globals and other types of SMEs (Bell et al., 2003; Kuivalainen et al., 2007; Cavusgil and Knight, 2015), with the former leveraging their knowledge-based resources when aiming for rapid internationalization (Knight and Cavusgil, 2004). Thus, a sample covering five industry sectors was sought: metal, furniture and food industry firms were selected to present the more traditional 
manufacturing industries, with the software industry and knowledge-intensive business services industries selected to present the more knowledge-intensive group. Moreover, by applying the definition of SMEs suggested by OECD (2008) and Knight (2001), we limited the search to those firms employing less than 500 people.

The Amadeus online database was used to draw up the initial sample. By using the limitations discussed above, 1147 SMEs were found. These firms were then contacted by phone and asked to participate in the study. To those who agreed to take part, an e-mail was sent with a link to the online survey. The survey itself was prepared with the online questionnaire tool Webropol, back-translated with the help of a professional translator and pre-tested with managers from two different fields. The prospective respondents were offered a printed questionnaire as an alternative, but no respondent took the offer, all preferred to respond online.

To those firms that had promised to participate in the survey, reminder e-mails were sent one week apart, up to four times each. When the data collection was concluded in July 2008, 298 SMEs had responded to the questionnaire, giving a response rate of 26 per cent. A total of 119 were listed as having foreign operations, and thus comprise the final sample in this study. At the time of the data collection, these internationally operating SMEs were, on average, 23 years old, employed an average of 77 people, and had an average turnover of 9.3 million Euros. The respondent managers could identify as a "managing director", "owner", or “other key person". Among the international firms, the vast majority (81) were managing directors, with 15 identifying themselves as owners and 18 as "other key person". Consequently, we conducted ANOVA tests among the key variables in order to ensure that the respondent type did not significantly influence the given responses. No statistically 
significant differences at the 5 per cent risk level were found, and thus all the responses in the sample were deemed adequate for the analysis. We also checked for non-response bias, following the suggestions by Armstrong and Overton (1977), and found no problems with the data.

\section{$\underline{3.2 \text { Measure Development }}$}

The measures for the strategy focuses were adapted from Knight and Cavusgil's born global study (2004). We included both the items describing unique products development and the items describing quality focus into a primary component factor analysis using varimax rotation, and when necessary dropped an item due to a poor fit to a factor (i.e., one exhibiting a low commonality or cross-loading on several factors). The resulting two-factor solution captured 61 per cent of the total variation. Consequently, a five-item scale for unique products development focus with adequate reliability (Cronbach's alpha $=0.80)$ was developed:

- Our primary product/service caters to a specialized need that is difficult for our competitors to match

- In our industry, our products/services represent a new, innovative approach to addressing the customer's basic need

- Compared with our main competitors' offerings, our products/services are unique with respect to design.

- Compared with our main competitors' offerings, our products/services are unique with respect to technology. 
- Compared with our main competitors' offerings, our products/services are unique with respect to performance.

The items for the quality focus factor also exhibited sufficient reliability as a scale (alpha $=$ $0.72)$ and were as follows:

- Emphasizing quality customer service is important to our firm's strategy in this market.

- Emphasizing product/service quality is important to our firm's strategy in this market.

- For us, success in this market is driven by truly satisfying the needs of our customers there.

Subjective international performance was measured via a set of 7-point Likert scale items which were designed to inquire about the extent of success of international operations of the firm from the point of view of the management. Thus, the scale essentially measured the international performance of the firm subjectively, similarly to Knight and Cavusgil's 2004 study. The items formed a one-factor solution capturing 77 per cent of the total variation and exhibiting high reliability (alpha $=0.95)$. While such a high Cronbach's alpha may in theory suggest potential redundancy between the individual items in the scale, the threshold itself is debatable (see e.g., Clark and Wilson, 1995), and the inter-correlations between the items remained at a feasible range. Thus, the final scale used included items as follows:

- Generally speaking, we are satisfied with our success in the international markets.

- We have achieved the turnover objectives we set for internationalization.

- We have achieved the market share objectives we set for internationalization.

- Internationalization has had a positive effect on our company's profitability.

- Internationalization has had a positive effect on our company's image. 
- Internationalization has had a positive effect on the development of our company's expertise.

- The investments we have made in internationalization have paid themselves back well.

We operationalized the difference between born globals and other SMEs by dividing the sample firms into two groups according to the definition of born globals by Knight and Cavusgil (1996). As a result, a dichotomous variable was created distinguishing between born globals ("1") and other types of SMEs (“0”). The rapidity of foreign market expansion was measured by the share of turnover the firm derived from foreign markets three years after the first entry. The three-year threshold has been suggested repeatedly in context of born global definitions (Knight et al., 2004; Knight and Cavusgil, 2005; Jones et al., 2011). Since born globals have been suggested to be distinguishable from other types of firms by their level of knowledge-intensity, we also controlled for the knowledge-intensity of the sample firms by creating a dichotomous variable denoting knowledge-intensive firms (the sample firms from software industry and knowledge-intensive business services - "1") and the other types of more traditional manufacturing SMEs (sample firms from metal, food and furniture industries - “0”). Finally, in our analysis we also controlled for firm size (as measured by number of employees) and age. The descriptive statistics and intercorrelations between the variables can be seen in table 1 .

(take in table 1) 
First, we conducted binary logistic regression analysis in order to test for $\mathrm{H} 1$ and $\mathrm{H} 2$, i.e., if the strategic focus of SMEs would determine whether they had become born globals or not. The results, as shown in table 2, provide support for H1. The model with the control variables was non-significant $($ Chi-square $=4.68, \mathrm{p}>0.05)$, with neither of the two control variable coefficients statistically significant. We included the main explanatory variables to the second regression model, and this model was significant at the 5 per cent risk level (Chi-square $=$ 13.31, $\mathrm{p}<0.05)$. In particular, the coefficient for unique products development was both positive and significant $(0.85, \mathrm{p}<0.05)$, indicating that the strategy of unique products development determined the likelihood of an SME having become born global. Interestingly, the strategy of quality focus did not have a similar effect, and the coefficient was in fact negative $(-0.66, \mathrm{p}>0.05)$. This implies that the non-born globals in the sample would have been more likely to adhere to the strategy of quality focus, although this result was not remotely significant in the statistical sense.

\section{(take in table 2)}

Next, we applied linear regression models in order to test if the strategic focus of SMEs in general was linked to the intensiveness of their international expansion (H3-H4). Table 3 illustrates the result, and while the model including only the control variables (model 1, table 3) was non-significant $(\mathrm{F}=2.46, \mathrm{p}>0.05)$, model 2 with all the variables included was statistically significant $(\mathrm{F}=2.79, \mathrm{p}<0.05)$, while explaining a fifth of the growth that the SMEs had achieved from foreign markets immediately following their internationalization (adjusted $\left.\mathrm{R}^{2}=0.19\right)$. Notably, the results were similar to table 2 in that higher levels of focus in unique products development were positively related to increased share of turnover from foreign markets $(\beta=0.35, \mathrm{p}<0.05)$, thus supporting $\mathrm{H} 3$. 
(take in table 3)

On the other hand, $\mathrm{H} 4$ did not receive support from the analysis, as the coefficient for quality focus was again negative and non-significant $(\beta=-0.22, \mathrm{p}>0.05)$. Interestingly, the industry type was negatively related to foreign market growth $(\beta=-0.36, p>0.05)$, indicating that the knowledge-intensive SMEs had not been successful in growing rapidly in terms of scale of their international operations. This was a surprising result, as extant research in general has supported the idea of knowledge-intensive firms internationalizing rapidly and intensely (Bell, 1995; Bell et al., 2003; Kuivalainen et al., 2007). However, in our sample, the knowledge-intensiveness of firms was negatively correlated with their born globalness (see table 1), and although the correlation was not significant, we suggest that may have been due to the nature of firms in the knowledge-intensive business services sector not fully aligning with that of the software industry (which is clearly an industry sector where born globals are prevalent; see Bell, 1995; Boter and Holmquist, 1996; Sharma and Blomstermo, 2003; Freeman et al., 2006).

Finally, we tested for H5 and H6, in order to investigate if the dual strategic focus would be linked to increased international performance in SMEs overall, as they have been linked in born globals specifically (Knight and Cavusgil, 2004). The results, shown in table 4, provide no support for these hypotheses. First, the controls-only model (model 1, table 4) was nonsignificant $(F=0.28, p>0.05)$. Similarly, the model with the strategy variables included (model 2, table 4) was also non-significant $(\mathrm{F}=1.13, \mathrm{p}>0.05)$, and neither unique products development $(\beta=0.19, \mathrm{p}>0.05)$ nor quality focus $(\beta=0.11, \mathrm{p}>0.05)$ coefficients were statistically significant. Therefore, no link was found between the strategic focus of SMEs and 
their international performance, a contrary result in comparison to that found in the born global context (Knight and Cavusgil, 2004).

\section{(take in table 4)}

In sum, the results suggest that the strategy of unique products development determines whether an SME can successfully realize its born global status, by internationalizing within three years of its foundation, while simultaneously growing its foreign share of turnover to more than a quarter of its total turnover. Interestingly, the strategy of quality focus is not a differentiating factor between different types of SMEs. This is a contrary result to that of born globals (Knight and Cavusgil, 2004) and may suggest that focusing on customer satisfaction in terms of experienced quality may be particularly relevant for born globals. However, we also note that there are various definitions of what constitutes a born global in extant literature, and the one used in our analysis is merely one of them. Innovativeness in product development, however, proves a significant factor differentiating born globals from other types of companies, and also predicts faster international growth immediately following the start of internationalization among the SMEs. This result is in line with Knight and Cavusgil's study, and thus extends the implications to SMEs in general.

The results further suggest that the dual business strategies may not have an influence on international performance of the SMEs. This result is contrary to that found by Knight and Cavusgil (2004), and may imply that the beneficial effect of a focused business strategy on product innovativeness or quality may be particularly heightened in born globals, while the more traditional SMEs may not expect similarly satisfactory results when internationalizing with such focus. This may further imply that strategic focus on innovativeness and product 
quality are competitive advantages unique to born globals, advantages that enable them to accrue international success whereas potential customers globally do not value the same product and service characteristics in non-born global SMEs. It may also be that there is an underlying factor which may explain these differences in more detail. For instance, in certain contexts, social and business networks may mediate a relationship between born globals and their performance: Zhou et al. (2007) provide such an example from the Chinese context, while several studies (e.g., Rasmussen and Madsen, 2001; Sigfusson \& Chetty, 2013) point towards similar implications on the importance of networking in a developed small open economy context. Individual business relationships (Agndal \& Chetty, 2007) as well as social capital (Chetty et al., 2008) may also have a relevant role. In addition, we also consider it possible that the market or institutional environment may moderate such relationships in the general SME context.

\section{IMPLICATIONS AND RELEVANCE FOR POLICY AND PRACTICE}

The results of this study point towards several implications for both managers and for public policy makers. First, they suggest that specific strategic focus towards innovation may enable an SME to internationalize rapidly and intensely, thus enabling it to become a born global rather than a gradually internationalizing company. This is a crucial implication, since born

global as a definition (see Rennie, 1993; Madsen and Servais, 1997; Knight and Cavusgil, 2004) merely distinguishes such firms, rather than providing managers of SMEs the strategic tools to help their company achieve born global status. By finding that emphasizing strategic focus towards unique products development will result in an SME becoming born global and in rapid foreign market expansion, we suggest that innovativeness may provide unique 
competitive advantage that help domestic SMEs to break into foreign markets. This is crucial in particular to SMEs originating from small, open economies such as Finland, that are characterized by small domestic markets and relatively high labor costs, where continued growth of enterprises can generally only be realized through internationalization.

Second, the results indicate that all strategic focuses are not created equal: emphasizing quality may not provide an SME a fast track into foreign markets, particularly in contexts such as ours where competitors tend to favor quality focus as well. This further implies that, in order for an SME to successfully realize rapid and intense internationalization, it may need to emphasize strategic focus that distinguishes it from its domestic competitors, rather than developing a focus similar to them. For public policy makers, this correspondingly implies that, instead of aiming to help SMEs enhance the strategic strengths prevalent in the industry and in the national context, public institutions should rather concentrate on helping companies develop in areas which are not their main operative strengths: As seen in the results, in the Finnish context this means supporting SMEs in their innovativeness-related, rather than quality-related strategies.

Such a decision in public policy towards supporting SMEs may have far-reaching results, as growth-seeking enterprises have a crucial role in becoming both significant employers as well as payers of substantial corporate tax, thus having a dual impact on national economies. For the managers of internationalization-seeking companies, the noted difference between unique products development- and quality-focused strategies further implies that strategies aimed at product differentiation carry potential for rapid growth through internationalization, growth that will not necessarily be available through quality-enhancing efforts. 
Third, the fact that neither of the strategic focuses were linked to subjective international performance (i.e., strategic success of internationalization, as measured by managerial assessment) emphasizes that internationalization may be unpredictable, enabling companies to grow rapidly, yet not in a way foreseen by the management when developing overall company strategy for internationalization. The internationalization process may therefore be, as Schweizer (2012) has suggested, a "muddling-through" process, one where rapid foreign market entry and expansion is facilitated by product-related strategies, rather than ex ante internationalization strategy as such. Managers of internationalization-seeking SMEs should therefore be wary of developing far-reaching market strategies aimed at specific internationalization outcomes, and instead concentrate on the product level. Correspondingly, public policy towards SMEs should therefore also be geared towards innovation-seeking, rather than internationalization-seeking strategic development.

Simultaneously, we note that different market contexts may require different focus: While strategies aimed at optimizing quality may not provide unique competitive advantage among SMEs in the Nordic context, other market areas (such as China and other developing markets) may still offer such possibilities for differentiation through quality. However, ours was a study conducted in the empirical context of Finland, and thus we are confident in its applicability in the context of similar small, open economies (e.g., Denmark, Norway, Sweden or Ireland). Therefore, as SMEs further proceed in expanding the scale and scope of their international operations, we suggest that SMEs may have to re-assess their product strategy depending on their subsequent target markets.

Still, for many a company, it is the first foreign market entry that proves a major challenge, one they need to overcome rapidly in order to achieve the growth they need to cover sunk 
costs, e.g., those committed to product R\&D. The main resulting implication for both public policy and managerial practice therefore remains that focus on innovation, conceptualized here as the strategic focus on unique products development, may present a key to overcome that challenge, and may be crucial to accelerating internationalization of SMEs, even as the results of that impact do not closely adhere to the formal organizational goals set for the internationalization process.

\section{CONCLUSION}

The aim of this study was to investigate how the product- and service-related business strategies of SMEs are linked to their internationalization outcomes. We further conceptualized these outcomes in terms of how rapidly and intensely SMEs were likely to internationalize (i.e., whether it could be defined as born global or not), whether these business strategies enabled them more rapid growth internationally (i.e., how rapidly their foreign share of turnover had grown in the years immediately following their internationalization), and whether the international performance of SMEs in general could be explained through the dual strategies of unique products development and quality focus, as was suggested by Knight and Cavusgil (2004) to be the case with born globals. Such an examination was called for, since the internationalization strategies of SMEs may differ depending on their knowledge-intensity (Bell et al., 2004), and knowledge-intensity is a main characteristic denoting a born global firm (Knight, 1996; Moen, 2002; Gabrielsson et al., 2008). In addition, the strategies of internationally operating SMEs have been examined in international entrepreneurship literature mainly through the lens of entry mode and internationalization path decisions, and thus providing a view of product- and service-based 
strategies in the context can contribute to offer an increasingly holistic view into the phenomenon of business strategies conducive to the internationalization of SMEs.

Our study also contains several limitations. A cross-sectional survey naturally limits the interpretation of causal relationships between the variables to hypothesizing based on theory and extant literature. A follow-up study could therefore be called for, in order to establish temporal relationships. We also note that for clarity, our investigation did not distinguish firms beyond born global -type SMEs and other types of SMEs. That is to say that we did not specifically consider firm types such as international new ventures (Oviatt and McDougall, 1994), which can be argued are distinct from born globals in general (see Coviello, 2015). As our sample is restricted to SMEs, it does not account for the possibility of larger born globals.

Due to our sample size, we also were not able to establish direct relationships through e.g., structural equation modeling, and thus examining the antecedents of the business strategies (e.g., international strategic orientations; see Knight and Cavusgil, 2004) is left for future research. Accordingly, we suggest that exploring moderation and mediation effects by business networks and networking (see Rasmussen and Madsen, 2001; Zhou et al., 2007; Sugfusson \& Harris, 2013) could shed further light on the dynamics between strategic focus and internationalization outcomes among SMEs. We also note that, as our sample is restricted to SMEs, it does not account for the possibility of larger born globals. Finally, organizational competencies were not part of our present study, and should be included in future analysis. However, by extending the view of the dual business strategies to the SME context in general, the present study contributes to increase our understanding of their role in determining the differences of business strategy on outcomes of not only born globals specifically, but SMEs in general. In doing so, it provides an extension to the results by Knight and Cavusgil (2004), 
by investigating the impact of strategic focus on internationalization outcomes while distinguishing between born globals and other types of SMEs.

\section{REFERENCES}

Agndal, H. \& Chetty, S. (2007). The impact of relationships on changes in internationalisation strategies of SMEs, European Journal of Marketing, 41 (11/12), 1449-1474.

Agndal, H., Chetty, S. \& Wilson, H. (2008). Social capital dynamics and foreign market entry, International Business Review, 17 (6), 663-675.

Andersson, S. \& Wictor, I. (2003). Innovative internationalisation in new firms: born globalsthe Swedish case. Journal of International Entrepreneurship, 1 (3), 249-275.

Armstrong, S.J \& Overton, T.S. (1977). Estimating nonresponse bias in mail surveys. Journal of Marketing Research, 14 (3), 396-402.

Autio, E., Sapienza,H.J. \& Almeida, J.G. (2000). Effects of age at entry, knowledge intensity, and imitability on international growth. Academy of Management Journal, 43 (5), 909-924.

Bell, J.(1995)- The internationalization of small computer software firms: A further challenge to "stage" theories. European Journal of Marketing, 29 (8), 60-75. 
Bell, J., Crick, D. \& Young, S. (2004). Small firm internationalization and business strategy an exploratory study of 'knowledge-intensive'and 'traditional' manufacturing firms in the UK. International Small Business Journal, 22 (1), 23-56.

Cavusgil, S.T. \& Knight, G. (2015). The born global firm: An entrepreneurial and capabilities perspective on early and rapid internationalization. Journal of International Business Studies, $46(1), 3-16$.

Cavusgil, S.T. \& Zou, S. (1994). Marketing strategy-performance relationship: an investigation of the empirical link in export market ventures. The Journal of Marketing, 58 (1), 1-21.

Chetty, S. \& Campbell-Hunt, C. (2004). A strategic approach to internationalization: a traditional versus a "born-global" approach. Journal of International Marketing, 12 (1), 57 81.

Clark, L.A. \& Watson, D. (1995). Constructing validity: Basic issues in objective scale development. Psychological assessment, 7 (3), 309-319.

Coviello, N. (2015). Re-thinking research on born globals. Journal of International Business Studies, 46 (1), 17-26.

Crick, D., \& Spence, M. (2005). The internationalisation of 'high performing'UK high-tech SMEs: a study of planned and unplanned strategies, International Business Review, 14 (2), 167-185. 
Freeman, S., Edwards, R. \& Schroder, B. (2006). How smaller born-global firms use networks and alliances to overcome constraints to rapid internationalization. Journal of International Marketing, 14 (3), 33-63.

Gabrielsson, M., Kirpalani, V.H.M., Dimitratos, P., Solberg, C.A. \& Zucchella, A. (2008). Born globals: Propositions to help advance the theory, International Business Review, 17 (4), $385-401$.

Gleason, K.C. \& Wiggenhorn, J. (2007). Born globals, the choice of globalization strategy, and the market's perception of performance. Journal of World Business, 42 (3), 322-335.

Jantunen, A., Nummela, N., Puumalainen, K. \& Saarenketo, S. (2008). Strategic orientations of born globals — do they really matter? Journal of World Business, 43 (2), 158-170.

Johanson, J. \& Vahlne, J.-E. (1977). The internationalization process of the firm: a model of knowledge development and increasing foreign market commitments. Journal of International Business Studies, Spring-Summer 1977, 23-32.

Johanson, J. \& Vahlne, J.-E. (2003). Business relationship learning and commitment in the internationalization process. Journal of International Entrepreneurship, 1 (1), 83-101.

Johanson, J. \& Vahlne, J.-E. (2009). The Uppsala internationalization process model revisited: from liability of foreignness to liability of outsidership. Journal of International Business Studies, 40 (9), 1411-1431. 
Johanson, J. \& Wiedersheim-Paul, F. (1975). The internationalization of the firm: four Swedish cases, Journal of Management Studies, 12 (3), 305-322.

Jones, M.V., Coviello, N. \& Tang, Y.K. (2011). International entrepreneurship research (1989-2009): A domain ontology and thematic analysis, Journal of Business Venturing, 26 (6), 632-659.

Knight, G. (1996). Born Global. Wiley International Encyclopedia of Marketing, 6.

Knight, G.A. (2001). Entrepreneurship and strategy in the international SME. Journal of International Management, 7 (3), 155-171.

Knight, Gary, Tage Koed Madsen, and Per Servais (2004), "An inquiry into born-global firms in Europe and the USA," International Marketing Review, 21 (6), 645-665.

Knight, G.A. \& Cavusgil, S.T. (1996). The born global firm: A challenge to traditional internationalization theory. Advances in international marketing, New York: Jai Press: 1126.

Knight, G.A. \& Cavusgil, S.T. (2004). Innovation, organizational capabilities, and the bornglobal firm. Journal of International Business Studies, 35 (2), 124-141.

Knight, G.A. \& Cavusgil, S.T. (2005). A taxonomy of born-global firms. Management International Review, 45 (3), 15-35. 
Knight, G., Madsen, T.K. \& Servais, P. (2004). An inquiry into born-global firms in Europe and the USA. International Marketing Review, 21 (6), 645-665.

Kuivalainen, O., Sundqvist, S-K. \& Servais, P. (2007). Firms Degree of Born-globalness, International Entrepreneurial Orientation and Export Performance. Journal of World Business, 42, 253-267.

Laanti, R, Gabrielsson, M. \& Gabrielsson, P. (2007). The globalization strategies of businessto-business born global firms in the wireless technology industry. Industrial Marketing Management, 36 (8), 1104-1117.

Lévesque, M. \& Shepherd, D.A. (2004). Entrepreneurs' choice of entry strategy in emerging and developed markets. Journal of Business Venturing, 19 (1), 29-54.

Madsen, T.K. \& Servais, P. (1997). The internationalization of born globals: An evolutionary process? International Business Review, 6 (6), 561-583.

Merrilees, B., Miller, D. \& Tiessen, J. (1998). Serendipity, leverage and the process of entrepreneurial internationalization, Small Enterprise Research, 6 (2), 3-11.

Meyer, K. \& Skak, A. (2002). Networks, serendipity and SME entry into Eastern Europe, European Management Journal, 20 (2), 179-188. 
Moen, Ø. (2002). The born globals: a new generation of small European exporters.

International Marketing Review, 19 (2), 156-175.

OECD (2008). Definition of small and medium sized enterprises (SMEs).

Oviatt, B.M. \& McDougall, P.P. (1994). Toward a theory of international new ventures. Journal of International Business Studies, 25 (1), 45-64.

Oviatt, B.M. \& McDougall, P.P. (2005). Defining international entrepreneurship and modeling the speed of internationalization. Entrepreneurship Theory and Practice, 29 (5), $537-554$

Rasmussen, E.S. \& Madsen, T.K. (2001). The Founding of the Born Global Company in Denmark and Australia: Sensemaking and Networking. Asia Pacific Journal of Marketing and Logistics, 13 (3), 75-107.

Rennie, M.W. (1993). Born global. McKinsey Quarterly, 4, 45-52.

Sharma, D.D. \& Blomstermo, A. (2003). The internationalization process of born globals: A network view. International Business Review, 12, 739-753.

Sigfusson, T. \& Chetty, S. (2013). Building international entrepreneurial virtual networks in cyberspace, Journal of World Business, 48 (2), 260-270. 
Sigfusson, T. \& Harris, S. (2013). Domestic market context and international entrepreneurs' relationship portfolios, International Business Review, 22 (1), 243-258.

Spence, M. (2003). International strategy formation in small Canadian high-technology companies-a case study approach. Journal of International Entrepreneurship, 1 (3), 277-296.

Schweizer, R. (2012). The internationalization process of SMEs: A muddling-through process. Journal of Business Research, 65 (6), 745-751.

Tornikoski, E. T. \& Newbert, S. L. (2007). Exploring the determinants of organizational emergence: A legitimacy perspective, Journal of Business Venturing, 22 (2), 311-335.

Tuppura, A., Saarenketo, S., Puumalainen, K., Jantunen, A. \& Kyläheiko, K. (2008). Linking knowledge, entry timing and internationalization strategy. International Business Review, 17 (4), 473-487.

Zhou, L., Wei-ping, W. \& Luo, X. (2007). Internationalization and the performance of bornglobal SMEs: the mediating role of social networks. Journal of International Business Studies, 38 (4), 673-690.

Zou, S. \& Cavusgil, S.T. (2002). The GMS: A broad conceptualization of global marketing strategy and its effect on firm performance. Journal of Marketing, 66 (4), 40-56. 
Table 1. Descriptives and intercorrelations of the variables used in hypotheses testing.

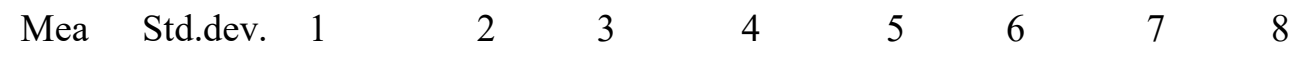

n

\begin{tabular}{lllll}
\hline 1 Unique & 4.70 & 1.05 & 1
\end{tabular}

Products

Development

\begin{tabular}{lllll}
\hline 2 Quality & 6.11 & 0.78 & $0.19^{*}$ & 1
\end{tabular}

Focus

\begin{tabular}{lllllll}
\hline 3 Foreign & 35.6 & 31.79 & 0.22 & -0.06 & 1 \\
Share of & 3 & & & & & \\
Turnover & & & & & & \\
\hline 4 Firm type & 0.55 & 0.50 & $0.27^{*}$ & -0.10 & $0.76^{* *}$ & 1 \\
(1=Born & & & & & & \\
Global, & & & & & & \\
$0=$ other $)$
\end{tabular}

\begin{tabular}{llllllll}
\hline 5 Subjective & 4.33 & 1.74 & 0.19 & 0.16 & $0.33 *$ & 0.04 & 1
\end{tabular}

International

Performance

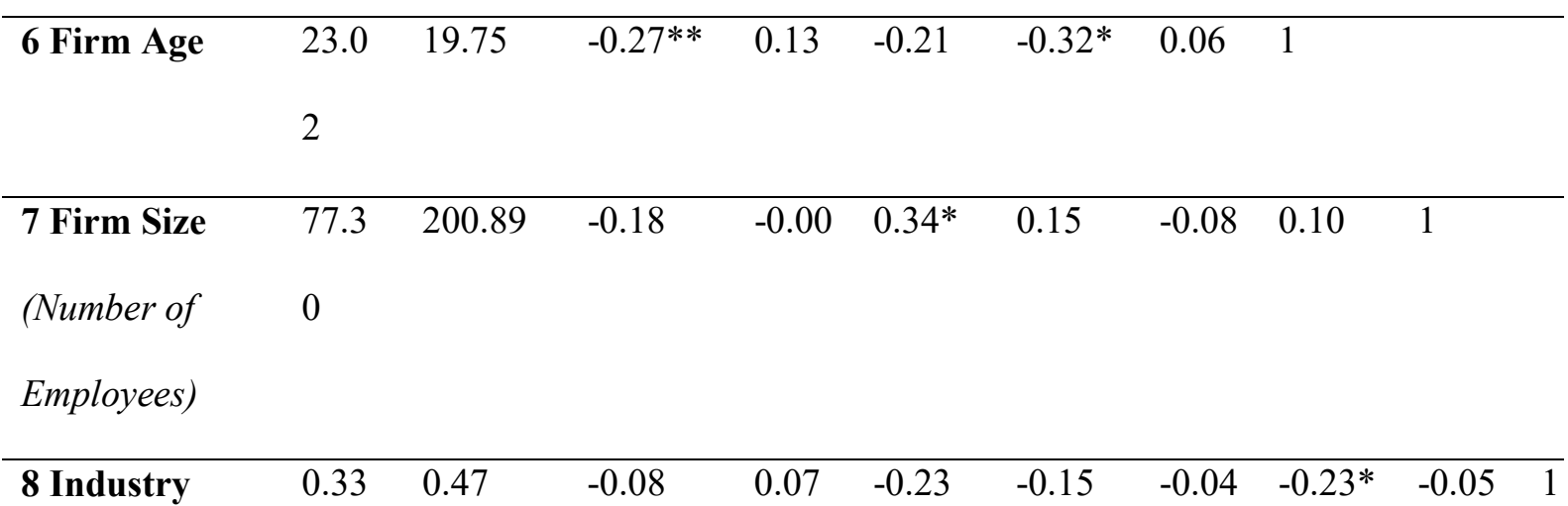

Sector

$(1=$ Knowledge-

int.,, $0=$ Other) 


$$
{ }^{* *} \mathrm{p}<0.01, * \mathrm{p}<0.05
$$

Table 2. Results of testing for $\mathrm{H} 1-\mathrm{H} 2$.

Dependent variable:

Firm Type

(1=born global, $0=$ other $)$
Model 1 (Controls

Only)
Model 2 (All Variables)

Independent variables:

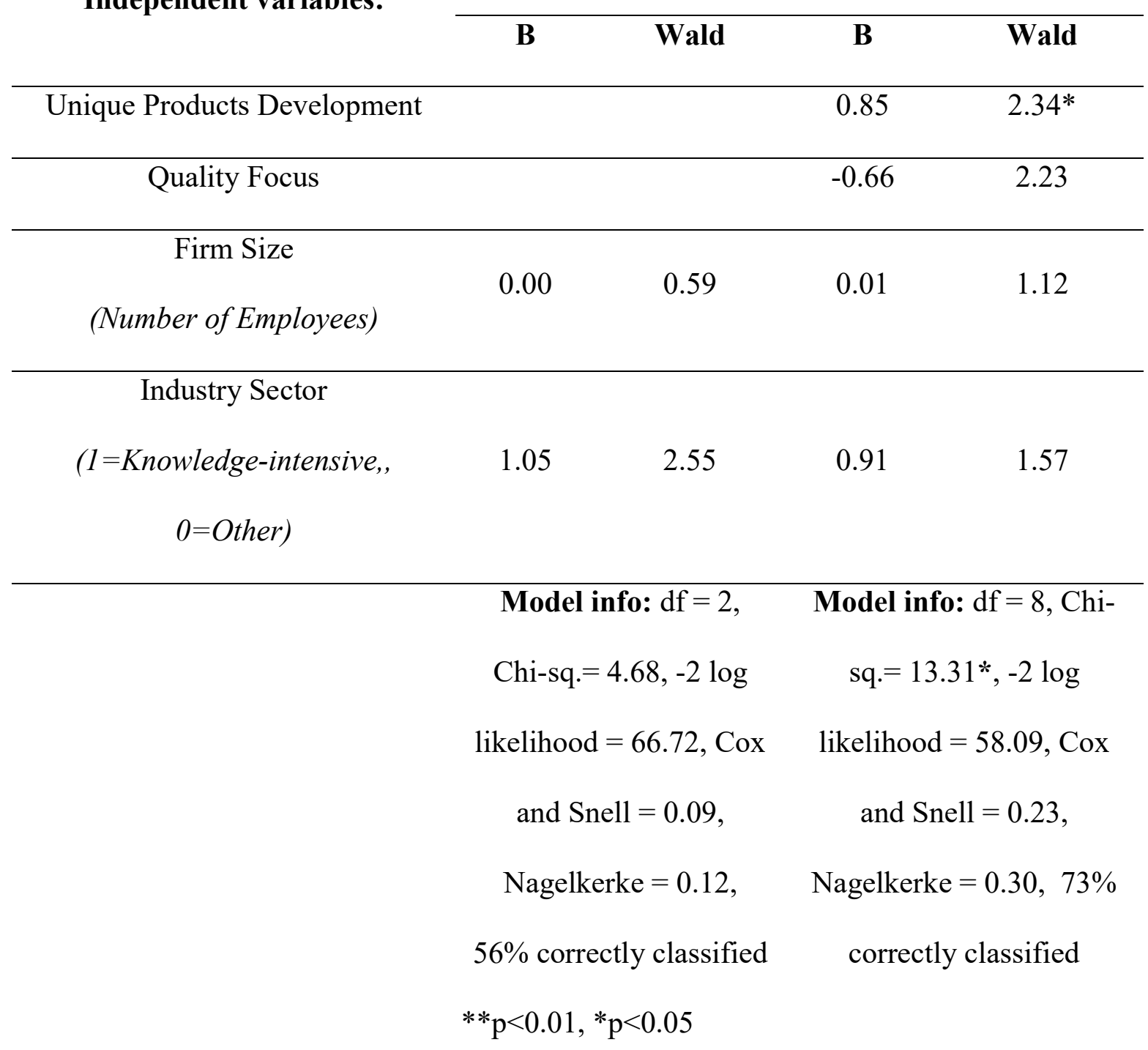


Table 3. Results of testing for international expansion (H3-H4).

\section{Dependent variable:}

Foreign share of turnover 3

Model 1

Model 2 (All

years after

internationalization

(Controls only) variables)

Independent variables:

$\beta$ t-value $\quad \beta \quad$ t-value

Unique Products

Development (UPD)

$0.35 \quad 2.22 *$

Quality Focus (QF)

$-0.22-1.44$

\begin{tabular}{|c|c|c|c|c|}
\hline Firm age & -0.30 & -1.84 & -0.18 & -1.08 \\
\hline $\begin{array}{c}\text { Firm size } \\
\text { (number of employees) }\end{array}$ & 0.01 & 0.09 & 0.02 & 0.11 \\
\hline $\begin{array}{c}\text { Industry } \\
\text { (knowledge-intensive }=1 \text {, } \\
\text { other }=0)\end{array}$ & -0.40 & $2.46^{*}$ & -0.35 & $-2.28 *$ \\
\hline $\operatorname{adj.} R^{2}$ & \multicolumn{2}{|c|}{0.10} & \multicolumn{2}{|c|}{0.19} \\
\hline $\mathrm{F}$ & \multicolumn{2}{|c|}{2.46} & \multicolumn{2}{|c|}{$2.79 *$} \\
\hline
\end{tabular}


Table 4. Results of testing for subjective international performance (H5-H6).

Dependent variable:

Subjective international

Model 1

Model 2 (All

performance

(Controls only)

variables)

Independent variables:

$\beta \quad$ t-value $\quad \beta \quad$ t-value

Unique Products
Development
0.19
1.61

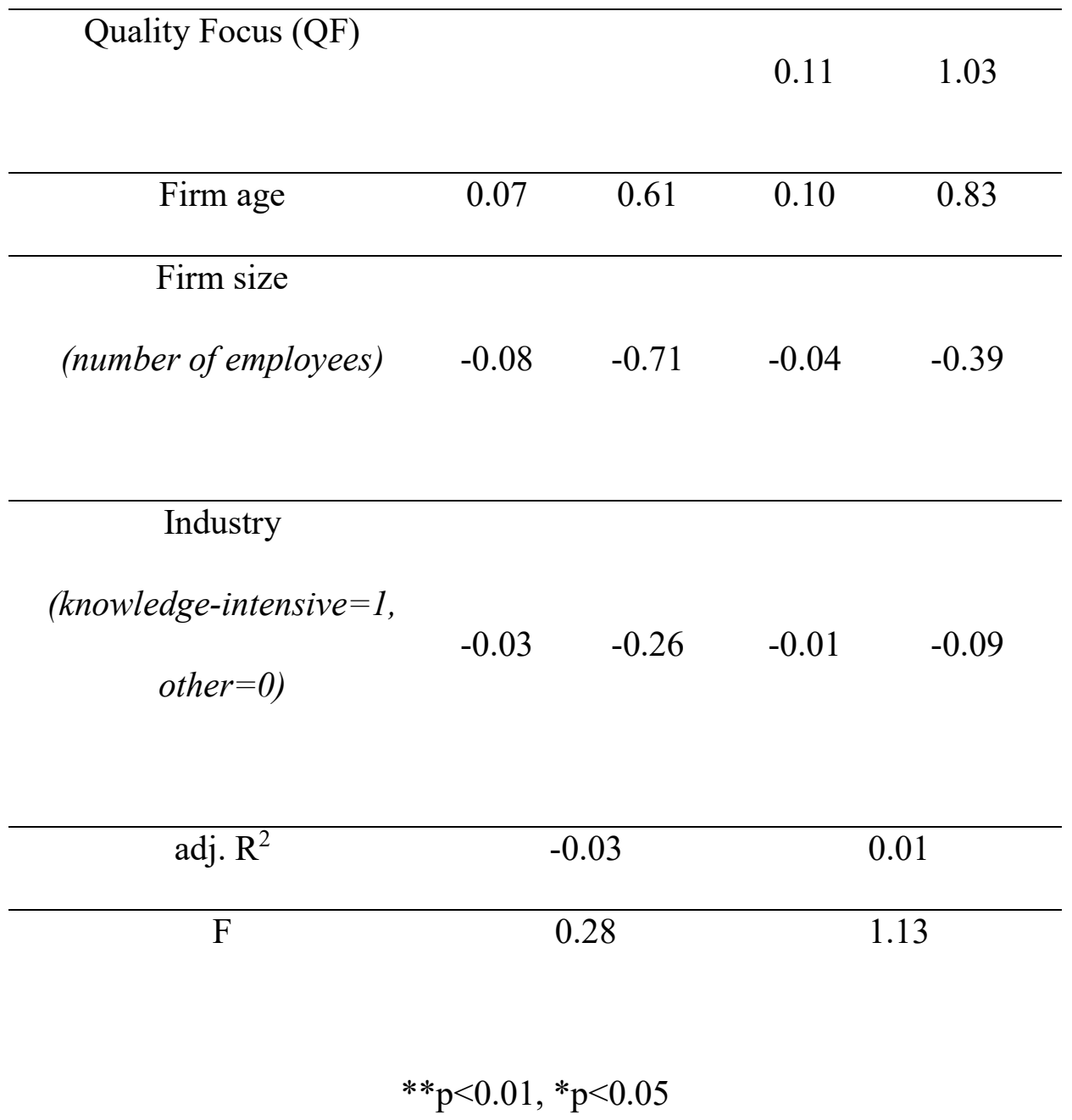

